\title{
Relationship between vegetation and soil formation in a rapidly submerging coastal marsh
}

\author{
J. A. Nyman ${ }^{1}$, R. D. DeLaune ${ }^{1}$, H. H. Roberts ${ }^{2}$, W. H. Patrick $\mathrm{Jr}^{1}$ \\ ${ }^{1}$ Wetland Biogeochemistry Institute, Louisiana State University, Baton Rouge, Louisiana 70803-7511, USA \\ ${ }^{2}$ Coastal Studies Institute, Louisiana State University, Baton Rouge, Louisiana 70803, USA
}

\begin{abstract}
Purposes of this study were to determine the relative importance of organic matter and mineral matter to marsh vertical accretion and to determine if insufficient vertical accretion was a factor in land loss in a Terrebonne Basin (Louisiana, USA) marsh. ${ }^{137} \mathrm{Cs}$ dating indicated that vertical accretion $\left(0.98 \mathrm{~cm} \mathrm{yr}^{-1}\right)$ was extremely rapid relative to other marshes, but insufficient to counter submergence $\left(1.38 \mathrm{~cm} \mathrm{yr}^{-1}\right)$. Mineral and organic matter accumulation were similar to that in other marshes. Variation in vertical accretion was accounted for by variation in organic matter accumulation rather than mineral matter accumulation; thus, inadequate vertical accretion resulted from inadequate organic matter accumulation. Inadequate organic matter accumulation ( $593 \mathrm{~g} \mathrm{~m}^{-2} \mathrm{yr}^{-1}$ ) was attributed to inadequale plant production resulting primarily from flooding stresses; inadequate mineral matter accumulation ( $1629 \mathrm{~g} \mathrm{~m}^{-2} \mathrm{yr}^{-1}$ ) was attributed to inadequate mineral matter availability. These data suggest that this marsh is threatened by a positive feedback loop of plant flooding stress and inadequate vertical accretion. Inadequate plant growth limits vertical accretion, which further increases flooding and decreases plant production. Thus plant production, which has previously been considered only in the context of trophic dynamics, also partly determines the degree of submergence some coastal and estuarine marshes will tolerate.
\end{abstract}

\section{INTRODUCTION}

Subsidence in coastal Louisiana, USA can exceed

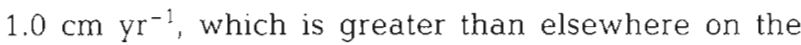
northern Gulf of Mexico coast (Penland \& Ramsey 1990). Marsh surfaces must vertically accrete by forming additional marsh soil if they are to counter submergence (the combination of global sea-level rise and subsidence). This process can be self regulating because as the marsh floods more often, tidal delivery of mineral sediments increases, and soil organic matter decomposition slows (Mitsch \& Gosselink 1986, p. 178). As the marsh surface regains elevation, mineral sedimentation decreases and soil organic matter decomposition increases (Mitsch \& Gosselink 1986, p. 178). However, soil formation can be inadequate (e.g. DeLaune et al. 1983a), which results in excessive marsh flooding. Soil waterlogging stresses can become severe enough to cause vegetation dieback (DeLaune et al. 1983b, Mendelssohn \& McKee 1988), which might lead to pond formation. Understanding marsh soil formation in Louisiana's rapidly subsiding coastal marshes may provide insight relevant to other coastal marshes if the rate of global sea-level rise increases as projected (e.g. Titus 1986).

Our primary purpose was to determine the relative importance of organic matter and mineral matter to marsh vertical accretion. Both mineral matter and organic matter are important components of marsh soil. In New England and Louisiana marshes, soil organic matter is composed primarily of tightly interlocking root networks that reduce the susceptibility of mineral sediments to erosion (McCaffrey \& Thomson 1980, J.A.N. pers. obs.). Organic matter accumulation defines vertical accretion in Louisiana and New England coastal marshes (McCaffrey \& Thomson 1980, Hatton et al 1983) but is apparently not as important in Atlantic coast marshes of the southeastern United States. In Louisiana, organic matter occupies more soil volume than mineral matter in fresh, intermediate, and brackish marsh soils (Nyman et al. 1990). Soil mineral matter may indirectly control vertical accretion 
through its effects on plant production (Bricker-Urso et al. 1989). King et al. (1982) reported a positive relationship between soil $\mathrm{Fe}$ concentrations and vegetation productivity in a Georgia marsh. Soil mineral matter provides cation exchange and sorption sites for orthophospate that reduce phosphate leaching (Patrick \& Khalid 1974), and soil P and saline marsh vegetation productivity are positively related in North Carolina (Broome et al. 1975). Bradley \& Morris (1990) observed a positive relationship between soil bulk density and soil water percolation velocity in South Carolina. Soil bulk density is a function of soil mineral matter content (Hatton et al. 1983), and end-of-season standing crop biomass of Spartina alterniflora is positively related to soil $\mathrm{P}$, soil $\mathrm{Fe}$, and soil bulk density in Louisiana saline marsh (DeLaune et al. 1979, DeLaune \& Pezeshki 1988). Mineral sedimentation is often a function of tidal action, but winter storms are more important in Louisiana (Reed 1989) and New England marshes (Harrison \& Bloom 1977, Stumpf 1983).

A secondary purpose was to determine if inadequate vertical accretion was a factor in marsh loss, as others have concluded (e.g. DeLaune et al. 1983a). Marsh loss in Louisiana is extremely rapid; Gagliano et al. (1981)

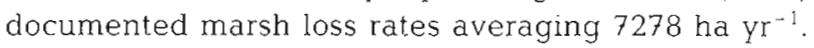
Marsh loss occurs in 2 landscape patterns in Louisiana (Leibowitz and Hill 1987) 'Hotspot' is a term coined by Leibowitz \& Hill (1987) to describe areas of high marsh loss rates embedded within areas of internal fragmentation where loss rates are much lower. Leibowitz \& Hill (1987) found that although hotspots accounted for only $12 \%$ of all marsh in their study areas, they accounted for $43 \%$ of all marsh loss.

\section{STUDY AREA}

The study area was in a sediment-poor interdistributary basin in southeastern Louisiana (Fig. 1). Soil was too fragile to support walking without sinking knee or thigh deep even in saline marsh. The northern limit of the study basin is the junction of Bayou Terrebonne and Bayou Barre. The basin is bounded by Bayou Terrebonne on the west, and by Bayou Barre on the east: to the south progressively lie Lake Barre. Terrebonne Bay, and the Gulf of Mexico. Pipeline canals indicate that petroleum extraction has occurred. Marsh loss rates in the study basin continue to increase even though these rates recently decreased throughout much of Louisiana (Britsch \& Kemp 1990). Conversion of marsh to open water averaged $320 \mathrm{ha} \mathrm{yr}^{-1}$ between 1974 and 1983 for the entire U.S. Geological Survey (USGS) Dulac 15 minute series topographic map (Britsch \& Kemp 1990). Much of this loss was concentrated in a large hotspot (roughly 600 ha) near mid-

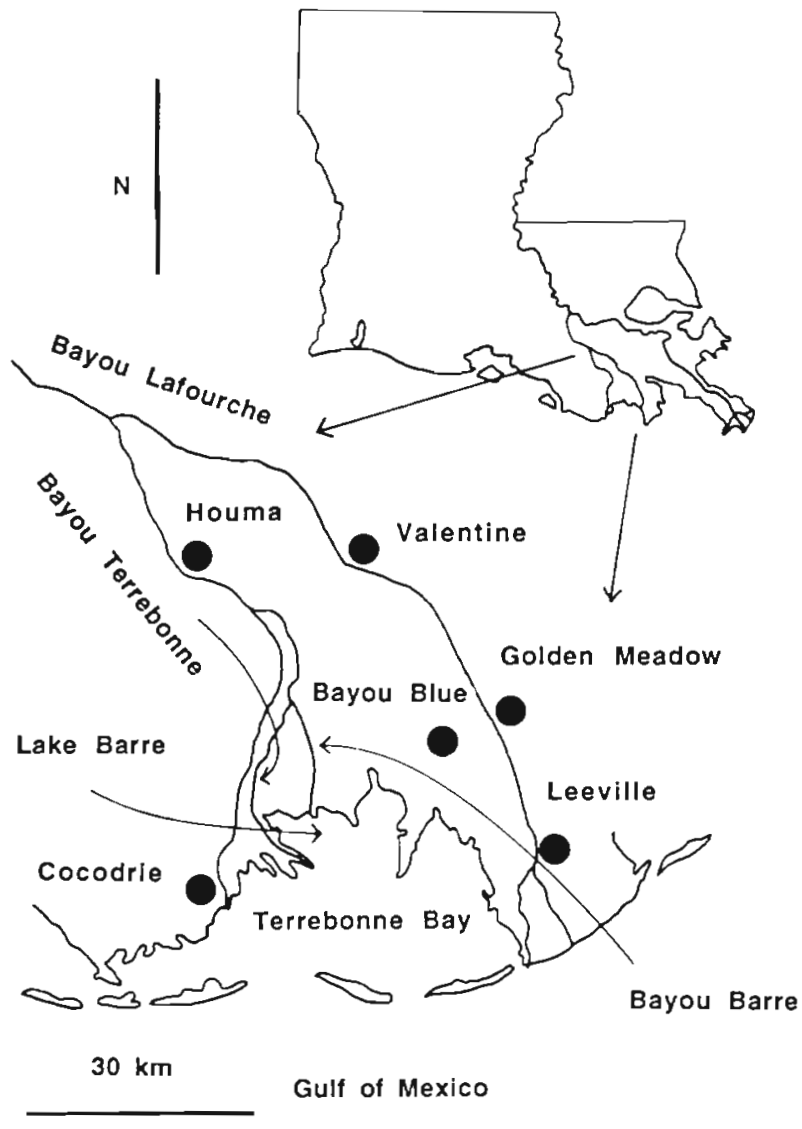

Fig. 1 Location of study area and tide gauge stations in Louisiana, USA, used to estimate submergence

basin where broken marsh was indicated on the 1964 USGS 15 minute series topographic map (Dulac quadrangle). The wetland loss maps prepared by May \& Britsch (1987) indicated that this hotspot formed after 1974. The landscape pattern was not a factor in selection of the study area.

The study area is part of the Lafourche delta complex. Bayous Terrebonne and Barre are distributaries of Bayou Lafourche, which shared the flow of the Mississippi River from roughly 4200 yr ago unitil 1904 when it was dammed at its upstream end (Frazier 1967) The most recent period of marsh building started roughly $800 \mathrm{yr}$ ago when the Mississippi River reoccupied Bayou Terrebonne, which progracted into shallow bays (Frazier 1967). The area is now in the delta Iobe abandonment phase (Coleman \& Gagliano 1964. Coleman 1988) and sediment dewatering and compaction cause subsidence as marine processes replace riverine process.

In 1949, vegetation in the southern portion of the study area was saline (Spartina alterniflora) and the northern portion was brackish (Scirpus olneyi) (O'Neil 1949). In 1990 and 1991, we noted only brackish/saline (S. patens and S. alterniflora) and saline marsh vegeta- 
tion ( $S$. alterniflora or $S$. alterniflora and Juncus roemerianus), although brackish marsh may have been present further north of our sampling stations. According to vegetation type maps (O'Neil 1949, Chabreck \& Linscombe 1988), the border between saline and brackish marsh has migrated approximately $5 \mathrm{~km}$ inland, from near Stn 5 to near Stn 13 (see Fig. 2). Inland migration of saline marsh at the expense of the brackish marsh is common in southeast Louisiana (Chabreck \& Linscombe 1982)

\section{METHODS}

Fifteen sites were sampled for analyses of soil formation (Fig. 2). Streamside marsh was not sampled; all sites were located in inland marsh, i.e. beyond $5 \mathrm{~m}$ from the edge of bayous and lakes. Three saline marsh sites were sampled in August 1989, others were sampled between February and August 1990. The 4 northernmost sites sampled in 1990 were in brackish/saline marsh; others were in saline marsh. Two soil cores were collected from each site. Cores were 45 to $55 \mathrm{~cm}$ long and were collected with $15 \mathrm{~cm}$ diameter, thin-

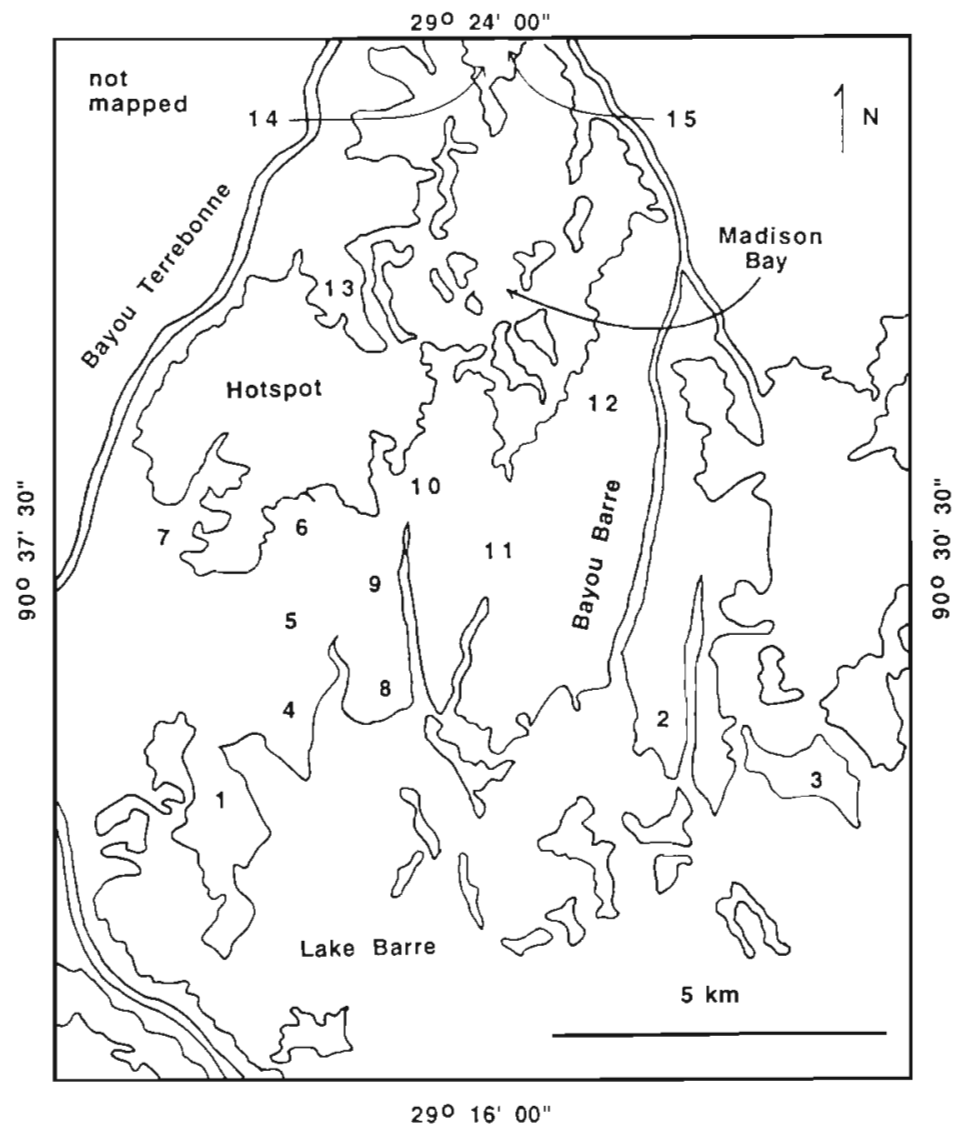

Fig. 2. Approximate location of sites where replicate cores were collected for study of soil formation walled, sharpened aluminum irrigation pipe. Cores were sectioned into $3 \mathrm{~cm}$ increments and dried at $80^{\circ} \mathrm{C}$ to remove non-structural water

Total vertical accretion on the marsh surface since 1963 was estimated from the depth of the soil increment containing the ${ }^{137} \mathrm{Cs}$ maxima, and the number of years between core collection and 1963 (DeLaune et al. 1978). Vertical accretion averaged over greater depths underestimates total vertical accretion (changes relative to shallow horizons) because of autocompaction, which causes marsh surfaces to settle (Kaye \& Barghoorn 1964). Vertical accretion averaged over greater depths is required to estimate net vertical accretion (changes in absolute elevation), which was not estimated in this study. ${ }^{137} \mathrm{Cs}$ activity was estimated from the gamma ray emission rate $(661.7 \mathrm{keV})$ from soil increments; standard deviations were also determined (Wang et al. 1975, p. 300). Entire soil increments were counted in a Marinelli beaker that fit over a $7.6 \mathrm{~cm} \times$ $7.6 \mathrm{~cm}$ Li drifted Ge detector crystal. The ${ }^{137} \mathrm{Cs}$ maxima were assumed to result from atmospheric deposition of ${ }^{137} \mathrm{Cs}$ that marks the 1963 surfaces, rather than from deposition of eroded, ${ }^{137} \mathrm{Cs}$-containing sediments that mark 1964 surfaces, as occurs in some reservoirs (Ritchie et al. 1973). This is because ${ }^{137} \mathrm{Cs}$ profiles in Louisiana marshes represent continual atmospheric deposition rather than discontinuous sediment deposition (pers, obs.). If we erred, then vertical accretion was underestimated by $4 \%$.

Vertical accretion rates were compared to published submergence estimates since 1963 to determine if vertical accretion in the study area was adequate to counter submergence. These local submergence rates more accurately reflect water level increases in the study area than does global sea level rise, because the local rates also reflect local subsidence, which is substantial in coastal Louisiana (Penland \& Ramsey 1990).

${ }^{137} \mathrm{Cs}$ mobility is not generally a problem because illites, the most common clays in nature (Millot 1970, p. 8), bind ${ }^{137} \mathrm{Cs}$ internally so that only destruction of the clay lattice (e.g. digestion with $5 \mathrm{~N}$ nitric acid) causes desorption (Lomenick \& Tamura 1965). Lomenick \& Tamura (1965) found $84 \%$ of the ${ }^{137} \mathrm{Cs}$ in their soil bound to illites even though illites accounted for only $35 \%$ of their sediments. Illites are the major clays in the Atlantic Ocean and make up 40 to $50 \%$ of the clays in the Gulf of Mexico (Griffin et al. 1968). Illites are common off the Louisiana coast (Brooks et al. 1976), in Louisiana estuarine sediments (Gambrell et al 1977), and account for 10 to $30 \%$ of 
mineral matter in Louisiana marsh soils (Dr W. Hudnall. Department of Agronomy, Louisiana State University Agricultural Center, Baton Rouge, pers. comm.). X-ray diffraction analyses of soil from the northern extreme, southern extreme, and middle of our study area indicated that illites were present in all samples (Dr Alan Bailey, Department of Geology, University of Southwestern Louisiana, Lafayette, pers. comm.). Illites are not common in freshwater bodies of the southeastern United States (Neiheisel \& Weaver 1967), and Alberts et al. (1979) noted ${ }^{137} \mathrm{Cs}$ mobility in a South Carolina freshwater reservoir that was subsequently explained by a lack of illites (Evans et al. 1983). See Ritchie \& McHenry (1990) for a recent review of ${ }^{137} \mathrm{Cs}$ dating applications.

Initial efforts also included ${ }^{210} \mathrm{~Pb}$ dating techniques to estimate vertical accretion (Armentano \& Woodwell 1975), but were discontinued when we found that our cores were not long enough to reach beyond depths containing atmospherically deposited ${ }^{210} \mathrm{~Pb}$ (unpubl. data). Evidently, vertical accretion rate was so rapid that these cores (about $50 \mathrm{~cm}$ long) were too short to reach soil $80 \mathrm{yr}$ old. This information was desired because it would have provided information relevant to autocompaction.

Bulk density in the study area was determined from the weight of oven-dried soil increments, and the volume of the increments prior to drying. Bulk density estimates from the upper 5 increments $(15 \mathrm{~cm})$ of each core were used to estimate root zone soil bulk density at the 15 sites throughout the study area.

The amount of organic matter and mineral matter that accumulated since 1963 in each core was also estimated. Soil increments that contained the 1963 marsh surface, and all overlying increments, were ground for analyses. Samples from each soil increment were ignited at $400^{\circ} \mathrm{C}$ for $16 \mathrm{~h}$ to remove organic matter (Davies 1974). The weights of mineral and organic matter per $\mathrm{cm}^{3}$ of soil in each increment were estimated from soil bulk density, percent mineral, and percent organic matter measured individually for each soil increment. Total mineral and organic matter accumulation could not be estimated for 2 cores from different sites because data were missing from individual increments in those cores

End-of-season, above-ground biomass of saline marsh vegetation was estimated to determine if vegetation in the study area was stressed, and also to determine if biomass variability within the study area was related to soil bulk density variability within the study area. Vegetation and soil bulk density were sampled on 26 October 1990. Four sites were selected that represented the range of Spartina alterniflora marsh vigor within the study area. These sites were not randomly chosen; instead, they were selected to document the range of vegetation biomass, from the most healthyappearing to the least healthy-appearing saline marsh vegetation stands in the study area. These sites were independent of the sites where cores were collected for soil formation analyses, although one was within $100 \mathrm{~m}$ of $\operatorname{Stn} 6$ (Fig. 2). At each biomass site, above-ground vegetation was harvested from three $0.5 \mathrm{~m}^{2}$ plots. A $20 \mathrm{~cm}$ long, $15 \mathrm{~cm}$ diameter core was also collected from the center of each plot to estimate soil bulk density at the biomass plots. As noted, soil bulk density from elsewhere in the study area was estimated from the 30 cores collected for soil formation analyses.

Vertical accretion, mineral matter and organic matter accumulation rates since 1963 and soil bulk density within the root zone were compared between brackish/saline and saline marsh as a Completely Randomized Design with nesting of site within marsh type (Proc GLM; SAS Institute, Inc., Cary, NC, USA); the site-within-marsh-type $(n=15)$ term was the proper
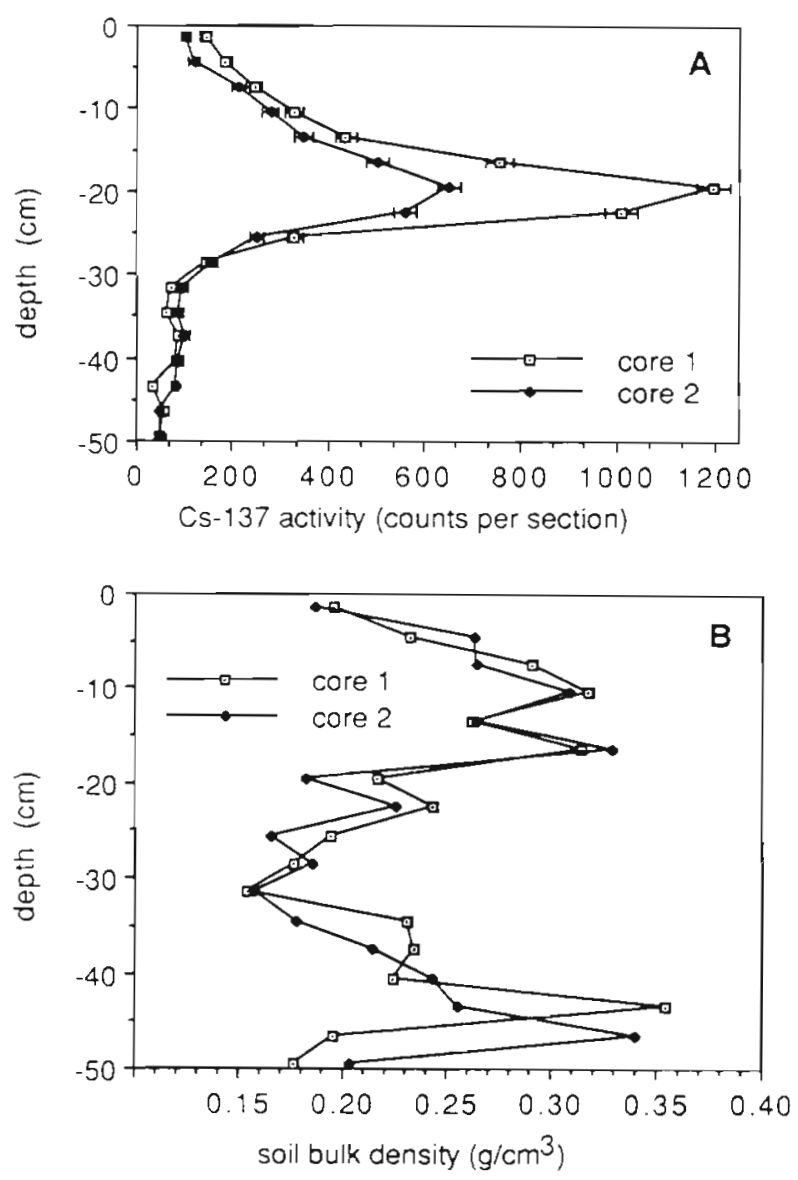

Fig. 3. (A) ${ }^{137} \mathrm{Cs}$ profiles and (B) soil bulk density profiles in replicate cores from a site in the study area. ${ }^{13} \mathrm{Cs}$ activity reflects continual atmospheric deposition, with peak levels in 1963. Soil bulk density reflects the discontinuous process of mineral sedimentation 
estimate of error for these tests rather than the corewithin-marsh-type $(n=30)$. All soil increments in the upper $15 \mathrm{~cm}$ of soil $(\mathrm{n}=148$ ) were used to estimate soil bulk density in the study area, but to be conservative, soil increments were considered sub-samples and were not used as independent estimates of error for statistical tests. Rather, the site-within-marsh-type term $(n=15)$ was used. Vertical accretion and mineral and organic matter accumulation were analyzed (Proc GLM; SAS Institute, Inc.) to determine whether organic matter accumulation, mineral matter accumulation, or their interaction was most strongly related to vertical accretion. For these regressions, type III 'uniquely attributable' sums of squares were used. This is especially important because mineral and organic matter accumulation were expected to be highly correlated, i.e. these data were expected to be ill-conditioned. Vegetation and soil bulk density data were analyzed (Proc REG; SAS Institute, Inc.) to test for a linear relationship between soil bulk density and saline marsh vegetation above-ground biomass within the study area. For all tests, an alpha level of 0.05 was used.

\section{RESULTS}

The 1963 marsh surface was almost always located at identical or adjacent depths in replicate cores from the same site (e.g. Fig. 3). Vertical accretion since 1963 in the study area averaged $0.98 \mathrm{~cm} \mathrm{yr}^{-1}$ ( $\mathrm{n}=30$, SE $=$ $0.06)$, and was similar in brackish/saline and saline marsh $(F=0.03,1$ and $13 \mathrm{df}, \mathrm{p}=0.8609$ ) (Table 1 ). There was no obvious spatial pattern in vertical accretion rates. Brackish/saline and saline marsh also had similar organic matter accretion rates $(F=0,14,1$ and $13 \mathrm{df}, \mathrm{p}=0.7111$ ), but differed greatly in mineral matter accumulation ( $F=5.95,1$ and $13 \mathrm{df}, \mathrm{p}=0.0298$ ) (Table 1).

Whereas ${ }^{137} \mathrm{Cs}$ profiles represented continual atmospheric deposition, variable soil bulk density with depth reflected the discontinuous process of mineral sedimentation (e.g. Fig. 3). Soil bulk density within the root zone, the upper $15 \mathrm{~cm}$ of soil, was lower in brackish/ saline marsh than in saline marsh $(F=22.11,1$ and 13 df, $p=0.0004$ ).

Vertical accretion was correlated with both mineral matter $(R=0.70, n=28, p=0.0001)$ and organic matter

Table 1 Soil formation characteristics in the Lake Barre area marshes; data from 2 cores at each site, Terrebonne Parish, Louisiand, 1989 and 1990

\begin{tabular}{|c|c|c|c|c|c|}
\hline Site & $\begin{array}{c}\text { Bulk } \\
\text { density } \\
\left(\mathrm{g} \mathrm{cm}^{-3}\right)\end{array}$ & $\begin{array}{c}\text { Organuc } \\
\text { matter } \\
(\%)\end{array}$ & $\begin{array}{l}\text { Vertical } \\
\text { accretion } \\
\left(\mathrm{cm} \mathrm{yr}^{-1}\right)\end{array}$ & $\begin{array}{c}\text { Mineral } \\
\text { accumulation } \\
\left(\mathrm{g} \mathrm{m}^{-2} \mathrm{yr}^{-1}\right)\end{array}$ & $\begin{array}{c}\text { Organic } \\
\text { accumulation } \\
\left(\mathrm{g} \mathrm{m}^{-2} \mathrm{yr}^{-1}\right)\end{array}$ \\
\hline \multicolumn{6}{|l|}{ Saline } \\
\hline (1) Lake Barre & 0.25 & 31.5 & 1.78 & 4178 & 1245 \\
\hline (2) Charles Theriot & 0.27 & 17.4 & 0.98 & 2083 & 440 \\
\hline (3) Bay la Peur & 0.31 & 24.4 & 0.78 & 2053 & 567 \\
\hline (4) downstream Chitigue & 0.27 & 21.2 & 0.98 & 2341 & 576 \\
\hline (5) midstream Chitigue & 0.26 & 21.9 & 0.75 & 1639 & 456 \\
\hline (6) upstream Chitıgue & 0.21 & 29.9 & 1.22 & 1928 & 720 \\
\hline (7) Grand Bayou ${ }^{\circ}$ & 0.18 & 31.0 & 1.04 & 1126 & 406 \\
\hline (8) downstream deMangue & 0.20 & 39.5 & 0.56 & 1376 & 439 \\
\hline (9) midstream deMangue & 0.26 & 23.5 & 1.28 & 2643 & 776 \\
\hline (10) upstream deMangue & 0.17 & 29.6 & 0.94 & 1100 & 624 \\
\hline (11) DuFrene & 0.16 & 31.3 & 0.55 & 699 & 310 \\
\hline Mean & 0.23 & 27.4 & 0.99 & 1992 & 613 \\
\hline \multicolumn{6}{|l|}{ Brackish/saline } \\
\hline (12) SE Madison Bay & 0.13 & 47.1 & 0.67 & 513 & 434 \\
\hline (13) W Madison Bay & 0.09 & 44.5 & 0.78 & 394 & 345 \\
\hline (14) N Madison Bay & 0.13 & 45.3 & 1.33 & 1054 & 796 \\
\hline (15) N Billy Goat Bay & 0.13 & 38.9 & 1.06 & 934 & 592 \\
\hline Mean & 0.12 & 44.0 & 0.96 & 724 & 542 \\
\hline Mean of all sites: & 0.20 & 31.8 & 0.98 & 1629 & 593 \\
\hline \multicolumn{6}{|c|}{$\begin{array}{l}\text { "Soil bulk density in the root zone only (top } 15 \mathrm{~cm} \text { of soil); all other parameters estimated from all soil overlying the } 1963 \\
\text { marsh surface }\end{array}$} \\
\hline \multicolumn{6}{|c|}{ Mineral and organic matter accumulation rates could be determined in only one core } \\
\hline
\end{tabular}




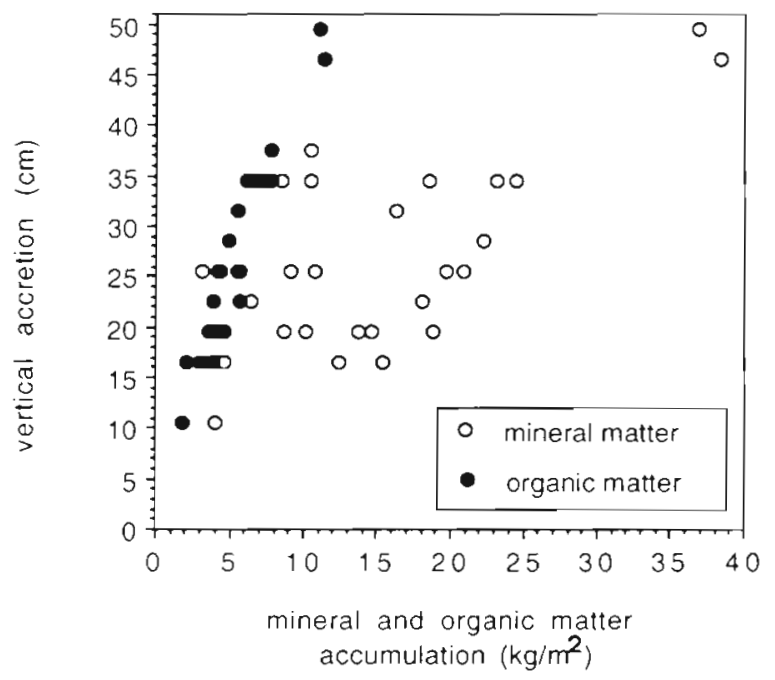

Fig. 4. Relationships between vertical accretion since 1963 and the amounts of mineral and organic matter accumulated since 1963 in the Lake Barre/Madison Bay study area, 1989-1990

accumulation ( $\mathrm{R}=0.95, \mathrm{n}=28, \mathrm{p}=0.0001)$. These Pearson correlation coefficients indicated that the linear relationship between vertical accretion and organic matter content was stronger than the linear relationship between vertical accretion and mineral matter (Fig. 4). Mineral matter accumulation and organic matter accumulation were also correlated $(R=0.75, n=28$, $p=0.0001$ ), thus these data were ill-conditioned as expected. A test of hypotheses with type III sums of squares indicated that vertical accretion was related to the amount of organic matter accumulated $(F=52.12,1$ and $23 \mathrm{df}, \mathrm{p}=0.0001$ ), but not to the amount of mineral matter accumulated ( $F=0.01,1$ and $23 \mathrm{df}, \mathrm{p}=0.9696)$. The interaction between mineral matter and organic matter was not significant $(F=0.05,1$ and $23 \mathrm{df}, \mathrm{p}=$ 0.8248 ). This analysis indicated that variation in vertical accretion that could be explained by mineral matter accumulation could also be explained by organic matter accumulation, but the reverse was not true. Partial. plots (Proc REG; SAS Institute Inc.) were also generated to test this interpretation of these ill-conditioned

Table 2. Saline marsh above-ground biomass and soil bulk density sampled at sites that represented the range of saline marsh vigor near Lake Barre, Louisiand, 1990

\begin{tabular}{|lrrrrrr|}
\hline & \multicolumn{3}{c}{ Biomass $\left(\mathrm{g} \mathrm{m}^{-2}\right)$} & \multicolumn{3}{c|}{ Bulk density $\left(\mathrm{gm}^{-3}\right)$} \\
& Mean & $\mathrm{n}$ & $\mathrm{SE}$ & Mean & n & $\mathrm{SE}$ \\
& & & & & & \\
\hline Hotspot only & 40.4 & 3 & 9.9 & 0.23 & 3 & 0.01 \\
$\begin{array}{l}\text { Other sites } \\
\text { All sites }\end{array}$ & 232.6 & 9 & 20.4 & 0.22 & 9 & 0.01 \\
& 184.5 & 12 & 29.3 & 0.23 & 12 & 0.0 \\
\hline
\end{tabular}

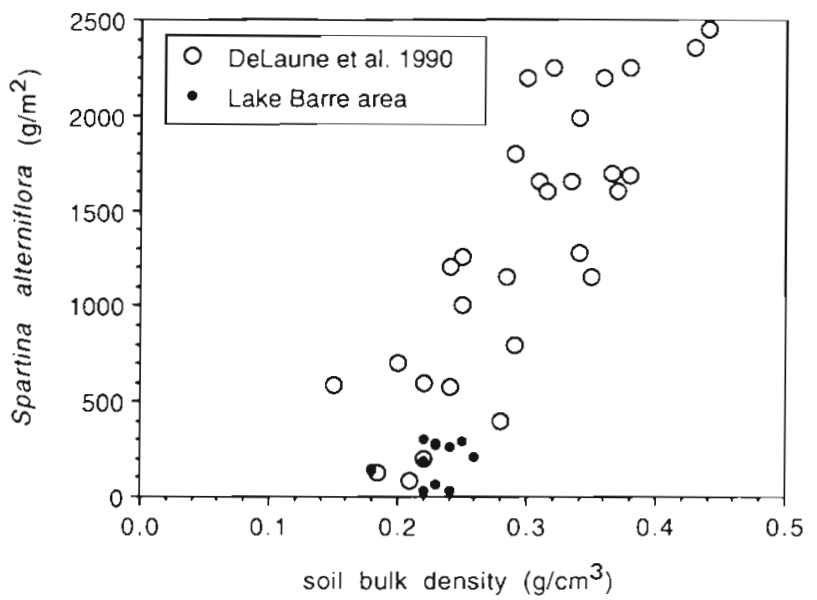

Fig. 5. Soil bulk density and biomass of Spartina alterniflora observed in this study $(O)$, in context with the relationship belween soil bulk density and S. alterniflora biomass reported by Delaune et al. (1990b) (d.)

data. They indicated no relationship between mineral matter accumulation and vertical accretion after adjusting for organic matter accumulation. However, a very strong linear relationship still existed between organic matter accumulation and vertical accretion after adjusting for mineral matter accumulation.

End-of-season, above-ground biomass was low even excluding samples from the site that appeared most stressed, which was near the hotspot (Table 2). Contrary to initial expectations, bulk density varied little among the biomass sites even though biomass varied greatly among them (Table 2). Regression analysis indicated no linear relationship between aboveground biomass and soil bulk density $(t=0.740,1$ and $10 \mathrm{df}, \mathrm{p}=0.4762$ ) overall, or when observations from near the hotspot were omitted $(t=2.341,1$ and $7 \mathrm{df}$, $\mathrm{p}=0.0518$ ). Either our sample size was too small, or factors other than soil bulk density caused biomass variability within the study area. Comparison of our data to data of Delaune et al. (1990a) indicated that bulk density was at the lower limits tolerated by Spartina alterniflora (Fig. 5). Thus, although biomass variability may not be related to bulk density variability within this study area, average soil bulk density and biomass in this study area was low relative to that previous data set.

\section{DISCUSSION}

Vertical accretion since 1963 was very high; at these sites it generally exceeded the rate for brackish and saline marshes in southeast Louisiana $10.72 \mathrm{~cm} \mathrm{yr}^{-1}$; Nyman et al. 1990). Even though vertical accretion in the study area was greater than elsewhere, it was 
Table 3. Submergence rates in the Lake Barre/Madison Bay area of Terrebonne Parish, Louisiana, estimated from tide gauge analysis, from Penland et al. (1988)

\begin{tabular}{|ccc|}
\hline Station & Period of record & $\begin{array}{c}\text { Submergence rate } \\
\text { (cm yr }{ }^{-1} \text { ) }\end{array}$ \\
\hline $\begin{array}{l}\text { Houma, Intracoastal } \\
\text { Waterway } \\
\text { Cocodrie, Bayou } \\
\quad \text { Petit Caillou } \\
\text { Valentine, Bayou } \\
\text { Lafourche }\end{array}$ & $1962-1982$ & $1.94 \pm 0.39$ \\
$\begin{array}{c}\text { Bayou Blue, } \\
\text { near Catfish Lake }\end{array}$ & $1969-1983$ & $0.60 \pm 0.32$ \\
$\begin{array}{c}\text { Golden Meadow, } \\
\text { Bayou Lafourche }\end{array}$ & $1959-1979-1982$ & $1.62 \pm 0.29$ \\
$\begin{array}{c}\text { Leeville, Bayou } \\
\text { Lafourche }\end{array}$ & $1957-1983$ & $1.02 \pm 0.46$ \\
$\begin{array}{c}\text { Mean of these } \\
\text { stations }\end{array}$ & $1964-1982$ & 1.38 (SD $=0.70)$ \\
\hline
\end{tabular}

inadequate to counter submergence. Estimated submergence since 1964 (the same time period over which vertical accretion was estimated) at 6 U.S. Army Corps of Engineers tide gauge stations surrounding the study basin averaged $41 \%$ greater than vertical accretion (Table 3). The most likely cause of the rapid submergence is the thick deposit of under-consolidated Holocene sediments in the study area, which are $180 \mathrm{~m}$ thick (Penland et al. 1988). Petroleum withdrawal has also occurred in the study area, but whether it increased subsidence in the study area is unknown. The vertical accretion deficit would have caused the marsh surface to lose $11 \mathrm{~cm}$ of elevation relative to mean water levels since 1964, even neglecting compaction below the 1963 marsh surface. This is quite large relative to average marsh elevation in Louisiana's flat marshes (about $30 \mathrm{~cm}$ above mean water levels; Chabreck 1970, p. 12), and would increase flooding stress on vegetation.

The actual vertical accretion deficit may be even greater than indicated by comparing our marsh surface vertical accretion rates to tide gauge submergence rates. This is because unlike tide gauge sites, the marsh surface is affected by oxidation of surface peats (DeLaune et al. 1990) and autocompaction of underlying peats (Kaye \& Barghoorn 1964). The tide gauges are anchored deeper and in more stable levee sediments adjacent to major Mississippi River distributaries that are more consolidated than bay fill and marsh deposits. Surface settling increases as peat thickness increases, and data available to Kaye \& Barghoorn (1964) suggested that peat thicker than $9 \mathrm{~m}$ caused autocompaction rates too great for marsh accretion to counter. Peat in this study area ranges only up to $1.5 \mathrm{~m}$. but lies on an additional $180 \mathrm{~m}$ of unconsolidated alternating Holocene bay fills and peats (S. Penland, Louisiana Geological Survey, pers. comm.).

Limited field observations also indicated that there was a vertical accretion deficit. During summer, we observed that the marsh surface did not completely drain even at extreme low tide. We observed marsh drainage only during winter when persistent north winds lowered water levels for extended periods of time. Continuous water-level data collected in the study area over an $11 \mathrm{~d}$ period during October 1990 indicated that, although there was a high and low tide each day, the marsh surface drained on only 7 days and only very briefly; the marsh surface was flooded more than $90 \%$ of the time during the $11 \mathrm{~d}$ period (from data in Reed et al.: 1991 unpublished Open File Report to U.S. Geological Survey, grant no. 14-080001-23320).

The vertical accretion deficit and resulting submergence, rather than lateral erosion, appeared to be the mechanism by which marsh converted to open water at the hotspot. There was no distinct interface between the hotspot and surrounding marsh; instead, hummocks of vegetation gradually gave way to open water with no obvious change in elevation. No evidence of lateral erosion was noted and plant stubble was still rooted in place beneath the water at areas that converted from marsh to open water during 1990 and 1991.

Vertical accretion must result from organic matter accumulation, mineral matter accumulation, or a combination of both. However, statistical analysis indicated that variation in vertical accretion among our sites was significantly related only to variation in organic matter accumulation among the sites. Apparently, differences in mineral sedimentation rates among the sites resulted primarily in differences in soil bulk density. Thus we concluded that vertical accretion in the study area depended directly on organic matter accumulation. We are unaware of other quantitative analyses to compare to our results, but others also concluded that organic matter accumulation controlled vertical accretion rates in Louisiana (Hatton et al. 1983) and New England marshes (McCaffrey \& Thomson 1980, Stumpf 1983, Bricker-Urso et al. 1989). This does not likely apply to mineral soil marshes such as those on the Atlantic coast of the southeastern United States.

Given that vertical accretion depended on organic matter accumulation, inadequate vertical accretion resulted from inadequate organic matter accumulation. Inadequate organic matter accumulation could result from either excessive decomposition, inadequate below-ground plant production, or a combination of both. However, excessive flooding such as 
occurs in the study area reduces both decomposition (Nyman et al. 1991) and production in Spartina alterniflora and S patens marsh (DeLaune et al. 1983b, Mendelssohn \& Mckee 1988, Pezeshki et al. 1991). Thus inadequate organic matter accumulation most likely resulted from inadequate production. Evidently, decreases in soil organic matter decomposition rates and increases in root/shoot ratios that are also expected with increased flooding (Good et al. 1982. Nyman \& DeLaune 1991) were not adequate. Given that plant production was limited by flooding, and that vertical accretion depended on organic matter accumulation, then a positive feedback loop of inadequate vertical accretion and plant flooding stress is indicated.

It would be incorrect to conclude from these data that mineral matter accumulation was unimportant to the vertical accretion process even though vertical accretion depended directly on organic matter accumulation. Organic matter accumulation probably depends partially on mineral matter accumulation because, as noted, soil mineral matter enhances plant growth. This is the most likely reason that organic matter accumulation and mineral matter accumulation were positively correlated. Others have also noted that organic matter accumulation and mineral matter accumulation were positively correlated, and concluded that this resulted from the positive effect of mineral sediments on plant growth (Bricker-Urso et al. 1989)

Brackish/saline marsh in this study area accreted vertically at rates similar to the saline marsh, but incorporated only $40 \%$ as much mineral matter as saline marsh. The difference in mineral matter accumulation between brackish and saline marsh may result from differences in mineral matter availability (e.g McCaffrey \& Thomson 1980 ) or because brackish and saline marshes differ in $\mathrm{SO}_{4}{ }^{2-}$ availability. This would cause

Table 4. End-of-season standing crop above-ground biomass in Louisiana saline marshes

\begin{tabular}{|c|c|c|}
\hline Habitat & $\mathrm{g} \mathrm{m}^{-2}$ & Source \\
\hline Streamside & 1540 & DeLaune et al. (1983b) \\
\hline Streamside & 1500 & Mendelssohn et al. (1981) \\
\hline Inland & 700 & Kirby \& Gosselink (1976) \\
\hline Inland & 850 & Hopkinson et al. (1978) \\
\hline Inland & 680 & DeLaune et al. (1983b) \\
\hline Inland & 900 & Mendelssohn et al. (1981) \\
\hline Dieback & 300 & Mendelssohn et al. (1981) \\
\hline Inland & 184 & This study \\
\hline
\end{tabular}

them to have different mineral matter requirements to counter different levels of sulfide toxicity (Nyman et al. 1990).

Spartina alterniflora biomass in the study area was low relative to other marshes (Table 4). This agreed with the conclusion that plant production was limited by the vertical accretion deficit and resulting flooding. Soil waterlogging reduces S. alterniflora photosynthesis (Pearson \& Havill 1988, Pezeshki et al. 1988), and soil drainage controls many of the factors proposed to limit $S$. alterniflora growth (Chalmers 1982). Aboveground production is related to end-of-season standing-crop biomass and stem turnover rates (Hopkinson et al. 1980), and stem turnover rates do not differ among different height forms of $S$. alterniflora. (Shrew et al. 1981). Thus, although above-ground production was not estimated, the biomass data collected indicated that current above-ground production was low as would be expected from excessive flooding. Although low biomass most likely resulted from excessive flooding, low soil bulk density may also have contributed to low S. alterniflora biomass. As noted, soil bulk density is a function of soil mineral matter content, and soil mineral matter and plant growth are positively related. It also appeared that high nutria $M$ Yocastor coypus and muskrat Ondatra zibethicus densities contributed to low $\mathrm{S}$. alterniflora biomass via herbivory, but no data are available to evaluate that relationship.

Mineral and organic matter accumulation rates were inadequate to offset submergence (Table 5: required value). Requirements were estimated from the submergence rate in this study area and typical soil prop- 


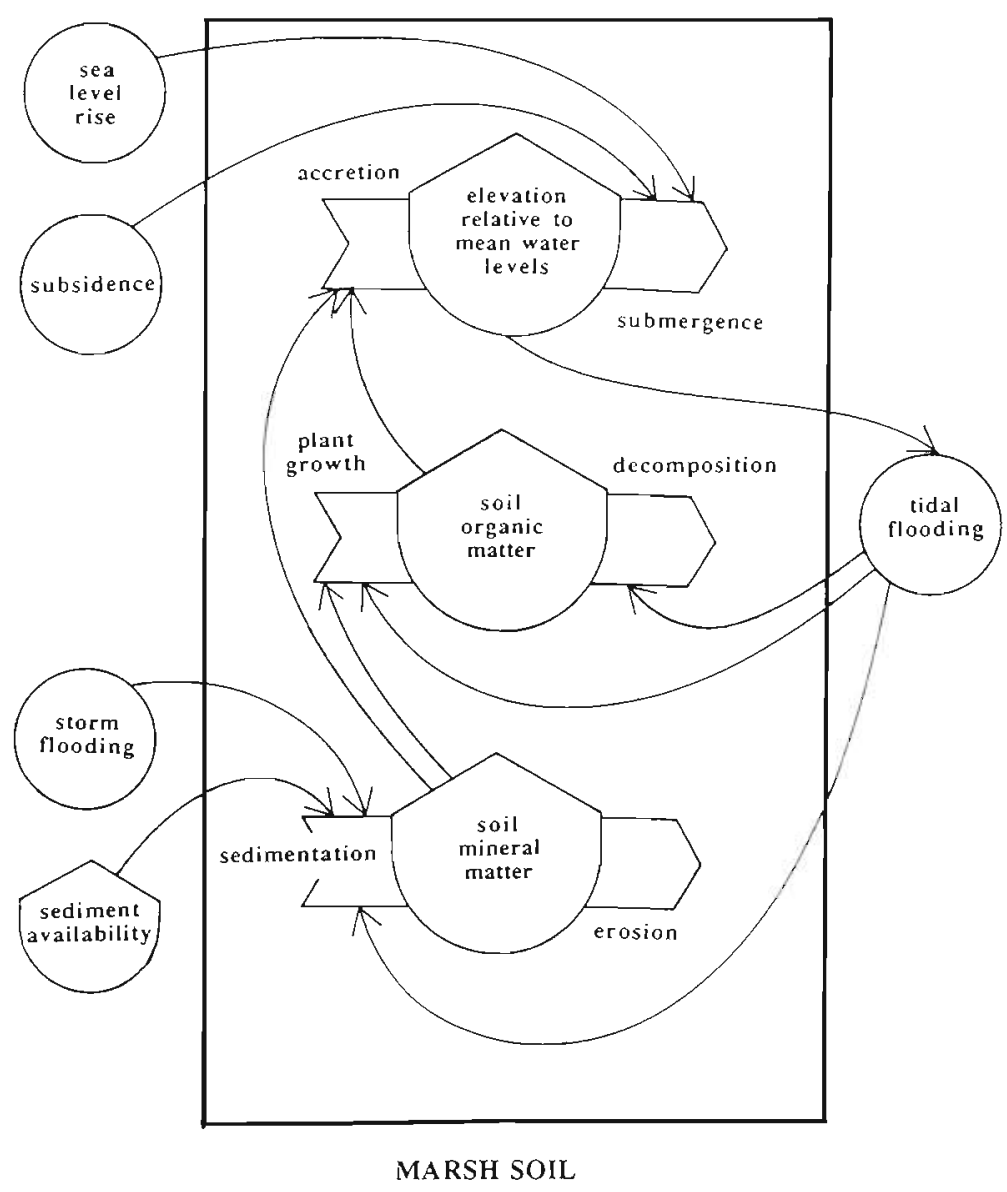

Fig. 6. Conceptual model of hypothesized interactions among soil formation processes during submergence. Vertical accretion can be adequate when increased flooding decreases soil organic matter decomposition and increases sedimentation (Mitsch \& Gosselink 1986, p. 178). Vertical accretion can be inadequate when flooding limits plant production and vertical accretion depends directly on organic matter accumulation. In this case, inadequate plant growth increases the vertical accretion deficit, which promotes another cycle of declining plant growth and increasing vertical accretion deficits

erties, according to Nyman et al. (1990: equations in Fig. 4). For instance, 1 vertical $\mathrm{cm}$ of brackish marsh soil usually contains $583 \mathrm{~g}$ of organic matter and $1052 \mathrm{~g}$ of mineral matter for each square meter of marsh. Thus $1.38 \mathrm{~cm} \mathrm{yr}^{-1} \times 583 \mathrm{~g} \mathrm{~m}^{-2} \mathrm{~cm}^{-1}=804 \mathrm{~g}$ $\mathrm{m}^{-2} \mathrm{yr}^{-1}$ of organic matter and $1452 \mathrm{~g} \mathrm{~m}^{-2} \mathrm{yr}^{-1}$ of mineral matter were required at our brackish sites. It is important to note that the accumulation rates were not low relative to other marshes (Table 5), thus even typical plant production may be inadequate during rapid submergence. Apparently, vertical accretion is self-regulating only during moderate submergence. Organic matter accumulation has an upper limit set by production; mineral matter accumulation has an upper limit set by mineral matter availability and the frequency of sedimentation events.

\section{CONCLUSIONS}

This marsh appears threatened by a hypothetical positive feedback loop of plant flooding stress and inadequate vertical accretion. Vertical accretion and plant growth are related because plant growth is a function of flooding, which depends partly on marsh elevation, and vertical accretion depends partly on organic matter accumulation (Fig. 6). Vertical accretion in our study area depends directly on organic matter accumulation, but plant growth supplies inadequate soil organic matter to counter submergence. Thus inadequate plant productivity may increase the vertical accretion deficit and initiate another cycle of declining plant production and increasing vertical accretion deficits (Fig. 6). There is no way to determine which came first: inadequate vertical accretion or inadequate organic matter accumulation. Changes in the subsidence rate and ephemeral plant stresses, such as high water or cyclic herbivory, are the most obvious triggering factors.

An important question is, what prevents the negative feedback system that commonly maintains marsh elevation from replacing this hypothetical positive feedback system (Fig. 6)? Although increased tidal flooding usually increases mineral matter accumulation (Mitsch \& Gosselink 1986, p. 178), tidal flooding is relatively unimportant to sedimentation in coastal Louisiana, and winter storms are more important (Reed 1989). Thus, the most important sedimentation events probably have not greatly increased in frequency even though tidal flooding increased. This, and the low sediment availability in the area, are the most likely reasons that the more common negativefeedback system has not replaced the hypothetical positive feedback system. Additional information regarding the relative importance of mineral and organic matter accumulation is needed to better understand marsh soil formation. Even though the situation indicated in this study area is not likely common in areas with typical subsidence rates, such information is required to determine if similar positive feedback situations might develop in other coastal marshes as a response to possible increases in the rate of global sea-level rise.

Acknowledgements. This work was supported by the U.S. Geological Survey under a multi-year program entitled 'Criti- 
cal Physical Processes of Wetland Loss', grant number 14-080001-23320. Dr L. R. LaMotte (Department of Experimental Statistics, Louisiana State University) provided statistical advice. John Callaway provided thoughtful conversation and critical reviews

\section{LITERATURE CITED}

Alberts, J. J., Tilly, L. J., Vigerstad, T J (1979). Seasonal cycling of cesium-137 in a reservoir. Science. 203: 649-651

Armentano, T V., Woodwell, G. M. (1975). Sedimentation rates in a Long Island marsh determined by ${ }^{210} \mathrm{~Pb}$ dating. Limnol. Oceanogr. 20: 452-456

Bradley, P. M., Morris, J. T (1990). Physical characteristics of salt marsh sediments: ecological implication. Mar Ecol. Prog. Ser. 61. 245-252

Bricker-Urso, S., Nixon, S. W., Cochran, J. K., Hirschberg, D. J., Hunt, C. (1989). Accretion rates and sediment accumulation in Rhode Island salt marshes. Estuaries 12 : 300-317

Britsch, L. D., Kemp, E. B. III (1990). Land loss rates: Mississippi River Deltaic Plain. Technical report GL-90-2. U.S. Army Engineer District, New Orleans

Brooks, R. A., Ferrel, R. E. Jr, Billings, G. K. (1976). Clay mineralogy of sediments on the Louisiana continental shelf. Trans. Gulf Coast Ass. geol. Soc. 26: 305-309

Broome, S. W., Woodhouse, W. W. Jr, Seneca, E. D. (1975). The relationship of mineral nutrients to growth of Spartina alterniflora in North Carolina: I. Nutrient status of plants and soils in natural stands. Soil Sci. Soc. Am. Proc. 39: 295-301

Chabreck, R. H. (1970). Marsh zones and vegetative types of the Louisiana coastal marshes. Ph.D. dissertation, Louisiand State University, Baton Rouge

Chabreck, R. H., Linscombe, R. G. (1982). Changes in vegetative types in Louisiana codstal marshes over a 10-year period. Louisiana Acad. Sci. 1982: 98-102

Chabreck, R. H., Linscombe, G. (1988). Louisiana coastal marsh vegetative type map 1988. Louisiana Department of Wildlife and Fisheries, Baton Rouge

Chalmers, A. G. (1982). Soil dynamics and the productivity of Spartina alterniflora. In: Kennedy, V S. (ed.) Estuarine comparisons. Academic Press. New York, p. 231-242

Coleman, J. M. (1988). Dynamic changes and processes in the Mississippi River delta. Geol. Soc Am. Bull. 100: 999-1015

Coleman, J. M., Gagliano, S. M. (1964). Cyclic sedimentation in the Mississuppi Ruver Deltaic Plain. Trans. Gulf Coast Ass. geol Soc 14:67-80

Davies, B. E. (1974). Loss-on-ignition as an estimate of soil organic matter. Soll Sci. Soc. Am. Proc. 38.150-151

DeLaune, R. D., Baumann, R. H., Gosselink, J. G. (1983a). Relationships among vertical accretion, coastal submergence, and erosion in a Louisiana Gulf Coast marsh. J. sediment. Petrol. 53: 147-157

DeLaune, R. D., Buresh, R. J., Patrick, W. H. Jt (1979). Relationship of soil properties to standing crop biomass of Spartina alterniflora in a Louisiana marsh. Estuar coast. mar. Sci. 8: 477-487

DeLaune, R, D., Pezeshki, S. R. (1988). Relatıonship of muneral nutrients to growth of Spartma alterniflora in Louisiana salt marshes. Northeast Gulf Sci 10: 195-204

DeLaune, R. D., Patrick, W. H. Jr, Van Breemen, N. (1990). Processes governing marsh formation in a rapidly subsiding coastal environment. Catena 17:277-288
DeLaune, R. D., Patrick, W. H. Jr, Buresh, R. J (1978). Sedimentation rates determined by ${ }^{137} \mathrm{C}$ s dating in a rapidly accreting salt marsh. Nature 275: 532-533

DeLaune, R. D., Smith, C. J., Patrick, W. H. Jr (1983b). Relationship of marsh elevation, redox potential, and sulfide to Spartina alterniflora productivity. Soil Sci. Soc. Am. Proc. 47: $930-935$

Evans, D. W., Alberts, J. J., Clark, R. A. III (1983) Reversible ion-exchange fixation of cesium-137 leading to mobilization from reservoir sediments. Geochim. cosmochim. Acta 47: $1041-1049$

Frazier, D. E. (1967). Recent deltaic deposits of the Mississippi River: their development and chronology. Trans. Gulf Coast Ass. geol. Soc. 17: 287-311

Gagliano, S. W., Meyer-Arendt, K. J., Wicker, K. M. (1981). Land loss in the Mississippi River Deltaic Plaın. Trans. Gulf Coast Ass. geol. Soc. 31: 295-300

Gambrell, R. P., Khalid, R. A., Verloo, M. G., Patrick, W. H. Jr (1977). Transformations of hedry metals and plant nutrients in dredged sediments as affected by oxidation reduction potential and $\mathrm{pH}$. Volume II Dredged Material Research Program contract report D-77-4. U.S. Army Engineer Waterways Experiment Station, Vicksburg, MS

Good, R. E., Good, N. F., Frasco, B. R. (1982). A review of prumary production and decomposition dynamics of the belowground marsh component. In: Kennedy, V.S. (ed.) Estuarine comparisons. Academic Press, New York, p. $139-158$

Griffin, J. J., Windom, H., Goldberg, E. D. (1968). The distribution of clay minerals in the World Ocean. Deep Sea Res. 15: $433-459$

Harrison, E. Z., Bloom, A. L. (1977). Sedımentation rates on tidal salt marshes in Connecticut. J. sediment. Petrol. 47 $1.484-1490$

Hatton, R. S., Delaune, R. D., Patrick, W. H. Jr (1983) Sedimentation, accretion, and subsidence in marshes of Barataria Basin, Louisiana. Limnol. Oceanog 28 $494-502$

Hopkinson, C. S., Gosselink, J. G., Parrondo, R. T (1978) Aboveground production of seven marsh plant species in coastal Louisiana. Ecology 59: 760-769

Hopkinson, C. S., Gosselink, J. G., Parrondo, R. T. (1980). Production of coastal Louisiana marsh plants calculated from phenometric techniques. Ecology 61. 1091-1098

Kaye, C. A., Barghoorn, E. S. (1964). Late quaternary sealevel change and crustal rise at Boston, Massachusetts, with notes on the autocompaction of peat. Geol. Soc. Am. Bull. 75: 63-80

Kearney, M. S., Stevenson, J. C. (1991). Island land loss and marsh vertical accretion rate evidence for historical sealevel changes in Chesapeake Bay. J. coastal Res. 7 403-4:5

King, G. M. Klug, M. J , Whiner, R. G., Chambers, A. G (1982). Relation of soil water movement and sulfide concentration to Spartina alterniflora production in a Georgia salt marsh. Science 218: 61-63

Kırby, C. J., Gosselink, J. G. (1976). Primary production in a Louisiana Gulf Coast Spartina alterniflora marsh. Ecology 57: $1052-1059$

Lesbowitz, S. G. Hill, J. M. (1987). Spatial patterns of Louisiana coastal land loss. In: Turner, R. E., Cahoon, D. R. (eds.) Causes of wetland loss in the coastal central Gulf of Mexico. Volume Il: Technical narrative. Contract No. 14 12-0001030252. OCS Study/MMS 87-0120. Final report submitted to Minerals Management Service, New Orleans, LA, p. 331-355 
Lomenick, T. F., Tamura, T. (1965). Naturally occurring fixation of Cesium-137 on sediments of Lacustrine Origin. Soil Sci. Soc. Am. Proc. 1965: 383. 387

May, J. R., Britsch, L. D. (1987). Geologic investigation of the Mississippi River Deltaic Plain - Land loss and land accretion. Technical Report GL-878-13. U.S. Army Corps of Engineers. Waterways Experiment Station, Vicksburg. MS (maps)

McCaffrey, R. J., Thomson, J. (1980). A record of the accumulation of sediment and trace metals in a Connecticut salt marsh. Adv. Geophysics 22: 165-236

Mendelssohn, I. A., McKee, K. L. (1988). Spartina alterniflora die-back in Louisiana: time-course investigation of soil waterlogging effects. J. Ecol. 76: 509-521

Mendelssohn, I. A., McKec, K. L., Patrick, W. H. Jr (1981) Oxygen deficiency in Spartına alterniflora roots: metabolic adaptation to anoxia. Science 214:439-441

Millot, G. (1970). Geology of clays. Springer-Verlag, New York

Mitsch, W. J., Gosselink, J. G. (1986). Wetlands. Van Nostrand Reinhold Co., New York

Neiheisel, J., Weaver, C. E. (1967). Transport and deposition of clay minerals, southeastern United States. J. sediment. Petrol. 37-1086-1116

Nyman, J. A., DeLaune, R. D. (1991). $\mathrm{CO}_{2}$ emission and soil Eh responses to different hydrological conditions in fresh, brackish, and saline marsh soils. Limnol. Oceanogr. 36(7): $1406-1414$

Nyman, J. A., DeLaune, R. D., Patrick. W. H. Jr (1990). Wetland soil formation in the rapidly subsiding Mississippi River Deltaic Plain: mineral and organic matter relationships. Estuar. coast. Shelf Sci. 31: 57-69

O'Neil, T (1949). Colored type map of the Louisiana coastal marshes. Louisiana Department of Wild Life and Fisheries, New Orleans

Patrick, W. H. Jr, Khalid, R. A. (1974). Phosphate release and sorption by solls and sediments: effect of aerobic and anaerobic conditions. Scrence 186: 53-55

Pearson, J., Havill, D. C. (1988). The effect of hypoxia and sulphide on culture-grown wetland and non-wetland plants. J. exp. Bot. 39: 363-374

Penland, S., Ramsey, K. E. (1990). Relative sea level rise in

This article was presented by G.W. Thayer, Beaufort, N. Carolina, USA
Louisiana and the Gulf of Mexico: 1908-1988. J coastal Res. 6: 323-342

Penland, S., Ramsey, K. E., McBride, R. A., Mestayer, J. D., Westphal, K. A. (1988). Relative sea level rise and deltaplain development in the Terrebonne Parish Region. Coastal Geology Tech. Report No. 4. Louisiana Geological Survey, Baton Rouge

Pezeshki, S. R., DeLaune, R. D., Lindau, C. W. (1988). Interaction among sediment anaerobiosis, nitrogen úptake, and photosynthesis of Spartina alterniflora. Physiologia Plantarum 74:561-565

Pezeshki, S. R., Delaune, R. D., Pardue, J H. (1992). Sediment addition enhances transpiration and growth of Spartina alterniflora in deteriorating Louisiana Gulf Coast salt marshes. Wetlands Ecol. Mgmt 1: 185-189

Pezeshki, S. R., Matthews, S. W., DeLaune, R. D. (1991). Root cortex structure and metabolic responses of Spartina patens to soil redox conditions. Envir. exp. Bot. 31: 91-97

Reed, D. J. (1989). Patterns of sediment deposition in subsiding coastal salt marshes, Terrebonne Bay, Louisiana: the role of winter storms. Estuaries 12: 222-227

Ritchie, J. C., McHenry, J. R. (1990). Application of radioactive fallout Cesium-137 for measuring soil erosion and sediment accumulation rates and patterns: a review. J environ. Qual. 19: 215-233

Ritchie, J. C., McHenry, J. R., Gill, A. C. (1973). Dating recent reservoir sediments. Limnol. Oceanogr. 18: 254-263

Shrew, D. M., Linthurst, R. A., Seneca, E. D. (1981). Comparison of production computation methods in a Southeastern North Carolina Spartina alterniflora salt marsh. Estuaries 4: $97-109$

Stumpf, R. P. (1983). The process of sedimentation on the surface of a salt marsh. Estuar. coast. Shelf Sci. 17: 495-508

Templet, P. H., Meyer-Arendt, K. J. (1988). Louisiana wetland loss: a regional water management approach to the problem. Environ. Mgmt 12:181-192

Titus, J. G. (1986). Greenhouse effect, sea level rise, and coastal zone management. Coastal Zone Mgmt J. 14 $147-171$

Wang, C. H., Willis, D. L., Loveland, W. D. (1975). Radiotracer methodology in the biological, environmental, and phys1cal sciences. Prentice-Hall Inc., Englewood Cliffs

Manuscript first received: September 18, 1992

Revised version accepted: March 18, 1993 

Although the pattern of declining fisheries landings suggests over-harvesting (Parker et al. 1992), there is an association between mortalities in the Channel Islands and a set of morphological conditions termed withering syndrome (WS) for which the most striking feature is a withered foot. Only a quick and stealthy tug can remove a healthy abalone. However, weakened abalone in late stages of the disease readily detach from the substrate. A weakened foot is not diagnostic for WS because a withered foot is a common terminal symptom of several abalone diseases. Other aspects of WS include color changes of the foot and epipodium and reduced gonadal size (Haaker et al. 1992, Kuris et al. unpubl.). Sites suffering from WS have abnormally high numbers of fresh, empty shells from all sizes of recently dead individuals (Haaker et al. 1992). These observations indicate that declines in abalone densities are, at least partially, independent of the commercial or sport fishery, and may be attributable to WS (because landed abalone must be of legal size and have an intact shell).

Although the cause of WS has been elusive, there are a number of proposed hypotheses. While the most complicated hypothesis involves 16 interacting causal factors (Davis et al. 1992), the only explicitly tested hypothesis is that a recently discovered, as yet undescribed, coccidian protozoan associated with kidney damage causes WS (Steinbeck et al. 1992). Rejection of this infectious agent as the cause of WS stems from the observation that it is present in all of the black abalone sampled (it may be present at higher intensities in healthy animals than in sick animals), and there is no association between coccidian intensity and increased WS pathology (Steinbeck et al. 1992, Friedman unpubl., Kuris \& Stevens unpubl.). However, at high intensities, gonad and right kidney weights were low (Kuris \& Stevens unpubl.).

Compared to other marine mass mortalities, the present episode provides some unique opportunities for study. The crash of black abalone populations has occurred over a long time ( $7 \mathrm{yr}$ and still ongoing). Also, several jurisdictional agencies (California Department of Fish \& Game, Channel Islands National Park, U.S. Fish \& Wildlife Services, Pacific Gas \& Electric Co.) monitor the region in which it occurred for a variety of purposes. Thus, this mass mortality had considerable prior background data and occurred slowly enough to permit study of its epidemiology.

\section{APPROACH}

Our objective was to determine what factors led to the epidemic. To separate mortality due to the fishery from losses due to WS, we concentrated our efforts on changes in the density of sub-legal individuals $(<14.6 \mathrm{~cm})$. This indicates fishery-independent mortality. It was also necessary to determine associations between the activities of the fishery and the dieoff associated with WS. To test the hypothesis that the fishery is the cause of the mass mortality, we examined the relationship between fishing pressure and sublegal abalone density at many locations throughout the Channel Islands. If the fishery was indirectly responsible for the die-off, we predicted a negative association between fishing intensity and changes in sub-legal abalone density. Further, if WS is an entity spread by human activities we expected that heavily fished areas, or those close to major ports, would become affected at early dates.

Some evidence suggests that El Niño periods with warm water temperatures were the initial cause of WS and the resultant mortality (Tissot 1988, 1990, Davis et al. 1992). A variant of this hypothesis is that because El Niño events reduce kelp abundance (Tegner \& Dayton 1987), and drift kelp is the main food source of black abalone (Cox 1962, Leighton \& Boolootian 1963, Douros 1987), black abalone may have starved to death (Tissot 1988, 1990). Evidence in support of the El Nino hypothesis includes: (1) the die-offs began soon after the strong El Niño of 1983-84, (2) in 1988, mortality occurred in association with warm water discharged from Diablo Canyon Nuclear Power Plant (Steinbeck et al. 1992), and (3) abalone at Año Nuevo, presumably north of the influence of El Niño, did not suffer from WS (Tissot 1988). However, the occurrence of WS after El Niño could have been happenstance and warm water may not have been the sole causal factor at Diablo Canyon since mortality did not occur in previous years with similar or warmer temperatures (Steinbeck et al. 1992).

We conducted a multi-site geographic analysis to test the observations of Tissot $(1988,1990)$. Three predictions arise from the hypothesis that El Niño was responsible for WS. We expected an association between the initiation of WS die-offs and periods of warmer than average water temperature. We also predicted a positive association between changes in abalone and kelp densities because warm water reduces kelp abundance and black abalone feed on kelp. Because sea urchins are a potential competitor for drift kelp (Tegner \& Levin 1982) and foraged aggressively after El Niño (Ebeling et al. 1985), we predicted a negative association between changes in abalone and urchin densities. We examined these relationships for potential time lags as the El Niño might have a delayed effect on abalone survivorship.

Two other causal hypotheses are that mortality was due to a pollutant or an infectious disease agent. Unlike the fisheries or the El Niño/starvation hypothe- 
ses, in which there is an established causal chain of events, the pollution and infectious disease hypotheses both rely on undiscovered agents. The gradual spread of WS from a central focus would be consistent with either an infectious process or the spread of a pollutant. Both of these possible causes would be supported by evidence that WS appears sooner in locations downstream of the prevailing currents than at upcurrent sites. Davis et al. (1992) suggest the abnormally high densities of black abalone led to stresses that triggered the mass mortality. If WS was a directly transmitted disease, we expected that areas with initial high population densities would suffer higher mortality rates. On the other hand, because a pollutant would tend to become diluted far from its source, we would expect mortality rates to decline at more distant locations if a pollutant rather than an infectious disease was the causative agent of WS.

\section{METHODS}

We used a correlational approach to determine if the spread of the epidemic was consistent with predictions stemming from the proposed hypotheses. We were able, in several cases, to compare the observed patterns with results of a more experimental nature. We first collected the available information on black abalone in the Channel Islands. Marine biologists associated with the Channel Islands National Park (CINP), California Department of Fish and Game, U.S. Fish and Wildlife Service and Oregon State University generously provided abalone population data and other helpful information. This information included biannual population surveys conducted by the Rocky Intertidal Communities Monitoring Program (Haaker et al. 1992) and data on kelp and sea urchin abundance. from the Kelp Forest Monitoring Program (Davis et al. 1992), both of the CINP. Biologists from the California Department of Fish and Game, Pacific Gas and Electric Company, and several commercial fishermen provided additional observations on WS.

Most populations in which WS was evident exhibited a decline in density over time that fit a form of the logistic curve. To estimate the rate at which WS spread through the monitored abalone populations and the date that it first affected density, we expressed the size frequency distribution for sub-legal sized abalone at each site as a relative frequency distribution. Then, using least squares methods, we fitted each relative frequency distribution to the following derived form of the logistic equation:

$$
N_{0}-N_{t}=\frac{N_{0}}{1+e^{d-r t}}
$$

where $N_{0}=$ the initial population size; $N_{1}=$ the population size at time $t_{i}$ and $a$ is a constant. The parameter $r$ of the logistic equation represents the intrinsic rate of change of a population. We used this value as an index of the mortality rate of each population and used the date at which the mortality reached $10 \%$ of the initial population as the date of initiation of the die-off at each site. For regularly visited populations where density data were not available, we recorded the date at which WS was first noted as the start of the die-off (California Department of Fish and Game, Marine Resources Division Nearshore Invertebrate Project Field Reports).

Monthly fishing intensity for each site was estimated by using reported landings of the black abalone fishery compiled by the California Department of Fish and Game. Fishermen report landings according to a numbered grid of blocks published as the 'Southern California Fisheries Chart'. Each block represents a square area of 10 minutes of latitude by 10 minutes of longitude. Because each block covers a large area, more than one site was occasionally within a block. To examine the relationship between fishing intensity and WS, we calculated the correlation (Pearson) between the proportional change in sub-legal abalone density and the tonnes of abalone landed for each site where such data were both available.

We obtained sea water temperatures at each site from the field notes of the biologists that conducted the abalone monitoring. In addition, to estimate regional effects of El Niño, we used a long-term record of daily sea water temperature collected at the University of California, Santa Barbara. Taking the average temperature record of each day of the year, over $10 \mathrm{yr}$, generated a seasonal average. This way it was possible to determine whether the temperature was unseasonably warm or cold during a particular die-off event. We determined the mean and $95 \%$ confidence limits for sea water temperatures recorded during die-offs. We then compared this with the 10 yr mean sea water temperature and the seasonally adjusted temperature for that date.

The Kelp Forest Monitoring Project of CINP provided anmual data on kelp density as presented in Davis et al. (1992). In short, these represent the total number of adult plants ( $>1 \mathrm{~m}$ high) per $\mathrm{m}^{2}$ along a fixed transect. Although these data do not quantify drift kelp, it is likely that there is a correlation between drift kelp and kelp density over the time scale sampled. Data on sea urchins were collected in a similar manner to the data on kelp density. We only used information from kelp forest sites that were near intertidal abalone sites. To examine the association of these variables with WS, we calculated the correlation between the proportional change in sub-legal abalone density and the proportional change in kelp or urchin density. 
In our geographic analysis, we investigated the association of the timing and rate of the die-offs with the distance of each site from the initial observation of WS (south side of Santa Cruz Island). Ocean distance measures between each site and the south side of Santa Cruz Island or the nearest port were obtained by applying mapping software to scanned charts. For each site, we examined these distances and the rate of the die-off for correlations with die-off date.

Ocean circulation maps (Resources Partnership 1974, Hendershott 1991) indicated that the prevailing currents were from the northeast but that seasonal variation allowed for occasional back-flow from the southwest. This back-flow indicated dispersal of an infectious agent or pollution was possible anywhere within the Southern California Bight but that transport to the northwest was less likely than transport to the southeast. We assumed that sites up-current (northwest) of the south side of Santa Cruz Island were, in effect, further removed from this location than sites that were down-current (southeast). To determine the 'current-adjusted' distance of sites up-current from the south side of Santa Cruz Island, we multiplied up- current ocean distances by a 'resistance' factor. We varied this resistance factor from 1 (no resistance) to 2 (heavy resistance) and then calculated the correlation coefficients associated with the date of each die-off and the distance from the south side of Santa Cruz. We predicted that if currents were important for the spread of WS, the association between die-offs and distance from the initial site would be stronger for levels of resistance greater than 1.

\section{RESULTS}

The available data on abalone densities, mortality rates, temperature, distances from the south side of Santa Cruz Island and the nearest ports, and landings for 18 sites on 7 Channel Islands are summarized in Table 1. Fishing mortality dissipated following declines in abalone density. There was no association between fishing intensity and changes in sub-legal abalone density whether measured at each site or for all sites and times pooled $(r=-0.074, \mathrm{df}=65, \mathrm{p}>0.05)$. The WS-associated mortality began at various sites on

Table 1. Date of initiation of die-off, initial black abalone Haliotis cracherodii density, mortality rate, water temperature, distances from the south side of Santa Cruz Island and the nearest port, and landings for each site in the California Channel Islands where abalone densities were available. Dates of the initiation of the die-off were estimated as a $10 \%$ decline in density or as observed in the field. Fishery landings represent 12 yr (1980 to 1991) sums by block number each site is in. Sea water temperatures shown are: (1) 10 yr UCSB (Univ. of California. Santa Barbara) average for each date of die-off, (2) temperature at UCSB for date of dieoff, or (3) temperature obtained at the site near peak of die-oft. Mortality rate was estimated as the logistic parameter $r$. Distance, in kilometers, of each site is shown from (1) the initial location of the die-off (south side of Santa Cruz Island), (2) the initial location of the dje-off factored for resistance against prevailing currents, and (3) the nearest port (Santa Barbara, Port Hueneme, or Long Beach). Initial, pre-die-off density is given as no. of individuals per $\mathrm{m}^{2}$ of fixed transect. Islands: ANA = Anacapa Island, $\mathrm{SBA}=$ Santa Barbara Island, $\mathrm{SCL}=$ San Clemente Island, $\mathrm{SCR}=$ Santa Cruz Island, $\mathrm{SMI}=$ San Miguel Island, SNI = San Nicolas Island, $\mathrm{SRO}=$ Santa Rosa Island. Site abbreviations as in Fig. 1. -: no records

\begin{tabular}{|c|c|c|c|c|c|c|c|c|c|c|c|}
\hline \multirow[t]{2}{*}{ Island } & \multirow[t]{2}{*}{ Site } & \multirow{2}{*}{$\begin{array}{c}\text { Die-off } \\
\text { date }\end{array}$} & \multirow{2}{*}{$\begin{array}{l}\text { Landings } \\
\text { (t) }\end{array}$} & \multicolumn{3}{|c|}{ Temperature $\left({ }^{\circ} \mathrm{C}\right)$} & \multirow{2}{*}{$\begin{array}{c}\text { Mortality, } \\
r\end{array}$} & \multicolumn{3}{|c|}{$\mathrm{km}$ from die-off start } & \multirow{2}{*}{$\begin{array}{l}\text { Initial } \\
\text { no. } m^{-2}\end{array}$} \\
\hline & & & & $\begin{array}{l}\text { UCSB } \\
\text { mean }\end{array}$ & $\begin{array}{c}\text { UCSB } \\
\text { on date }\end{array}$ & $\begin{array}{l}\text { At } \\
\text { site }\end{array}$ & & $\begin{array}{l}\text { From } \\
\text { start }\end{array}$ & $\begin{array}{l}\text { With } 1.5 \\
\text { current }\end{array}$ & $\begin{array}{l}\text { From } \\
\text { port }\end{array}$ & \\
\hline ANA & M & Feb 1986 & 0.8 & 14.0 & 13.9 & 13.8 & 2.13 & 24.7 & 24.7 & 22.3 & 70 \\
\hline ANA & W & Aug 1986 & 0.8 & 18.0 & 16.7 & 17.1 & 2.18 & 22.3 & 22.3 & 25.9 & 26 \\
\hline $\mathrm{SBA}$ & SL & Jun 1988 & 3.7 & 17.4 & 17.3 & 16.7 & 24.0 & 79.9 & 80.0 & 74.1 & 5.4 \\
\hline $\mathrm{SCL}$ & AP & Jun 1990 & 2.3 & 17.4 & 18.3 & - & - & 143 & 143.0 & 94.1 & - \\
\hline $\mathrm{SCL}$ & EE & Jun 1990 & 68 & 17.4 & 18.3 & - & - & 64.7 & 149.0 & 100 & - \\
\hline SCL & NE & Jun 1990 & 68 & 17.4 & 18.3 & - & - & 149 & 155.0 & 107 & - \\
\hline SCR & $E X$ & Jul 1987 & 0.9 & 17.7 & 16.7 & 16.3 & 2.31 & 31.7 & 50.8 & 45.9 & 37 \\
\hline $\mathrm{SCR}$ & PR & Mar 1987 & 0.9 & 14.4 & 14.3 & 15.7 & 3.59 & 31.7 & 50.8 & 45.9 & 50 \\
\hline SMI & $\mathrm{CH}$ & Jun 1990 & 163 & 17.4 & 18.3 & - & - & 155 & 103.0 & 72.9 & - \\
\hline SMI & $\mathrm{CP}$ & Jun 1990 & 163 & 17.4 & 18.3 & 13.9 & 0.65 & 68.2 & 109.0 & 81.1 & 41 \\
\hline SMI & $\mathrm{HP}$ & Jul 1990 & 163 & 17.7 & 18.7 & - & - & 68.2 & 109.0 & 74.1 & 14 \\
\hline SMI & $\mathrm{OH}$ & Nov 1988 & 163 & 15.0 & 13.1 & - & - & 72.9 & 117.0 & 78.8 & 26 \\
\hline SNI & $\mathrm{RC}$ & Mar 1992 & 86 & 14.4 & 17.4 & - & - & 77.6 & 77.6 & 101 & - \\
\hline SRO & $\mathrm{EP}$ & Jun 1988 & 2.3 & 17.4 & 17.3 & 18.0 & 24.2 & 29.4 & 47.0 & 58.8 & 1.1 \\
\hline SRO & FP & Jul 1986 & 3.5 & 17.7 & 15.2 & 14.4 & 1.55 & 37.6 & 60.2 & 67.0 & 23 \\
\hline SRO & FR & Jan 1989 & 1.9 & 14.0 & 13.4 & - & 2.43 & 61.1 & 97.8 & 75.3 & 25 \\
\hline SRO & $J L$ & Jul 1986 & 3.5 & 17.7 & 15.2 & 14.4 & 1.56 & 40.0 & 64.0 & 70.6 & 42 \\
\hline SRO & NT & Aug 1988 & 43 & 18.0 & 16.1 & 14.0 & 1.36 & 57.6 & 92.2 & 67.0 & 12 \\
\hline
\end{tabular}




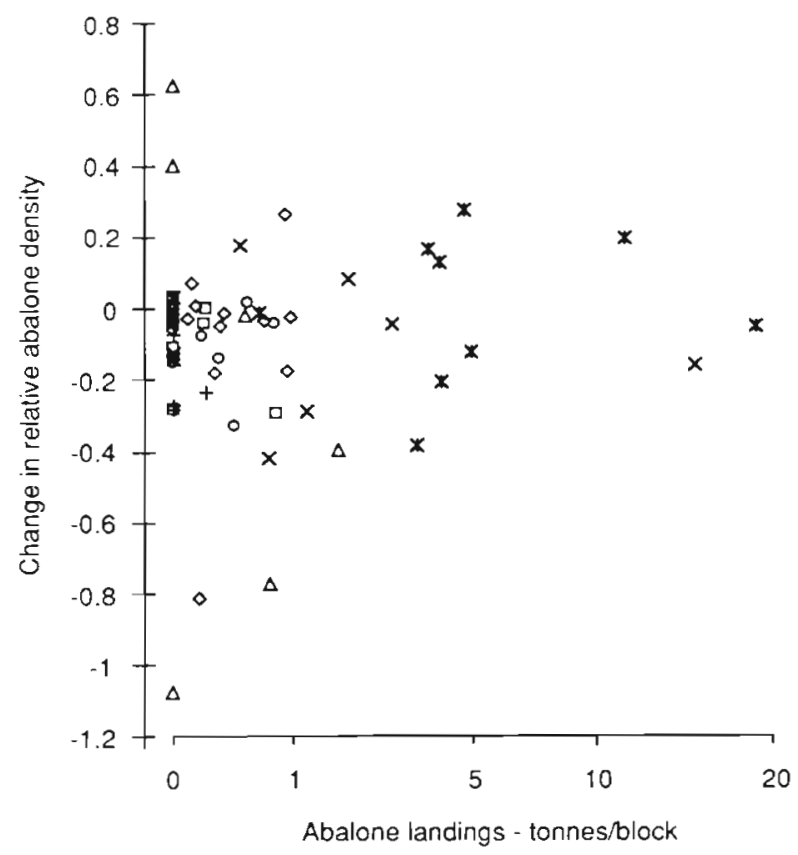

Fig. 2. Haliotis cracherodii. Changes in abalone density at 7 sites and the level of harvesting that occurred at each location for the same time period. Points represent biannual samples. (ㅁ) $\mathrm{M}_{1}(\infty) \mathrm{SBA},(\Delta) \mathrm{EP},(0) \mathrm{FP},(\times) \mathrm{NT},(+) \mathrm{FR},(*) \mathrm{OH}$ (site abbreviations as in Fig. 1)

different dates and proceeded at different rates. Contrary to the over-harvesting hypothesis, die-offs occurred later at heavily fished areas (Fig. 2; $\mathrm{r}=0.282$, $\mathrm{df}=70, \mathrm{p}<0.05$ ). There was also no relationship between the dates of die-offs and the distance of each site to the closest port ( $\mathrm{r}=$ $0.040, \mathrm{df}=16, \mathrm{p}>0.05$ ).

We found that the die-offs occurred, on average, during warmer periods $\left(16.5 \pm 0.8^{\circ} \mathrm{C}\right.$, $95 \% 2$-tailed confidence interval) than the 10 yr mean sea water temperature $\left(15.9^{\circ} \mathrm{C}\right)$. This difference was significant for the 1 -tailed prediction that warm water is associated with the die-off. However, when we adjusted these values for seasonality, we found that die-offs occurred at $0.05 \pm 0.7^{\circ} \mathrm{C}$ below the seasonal average. In other words, die-offs were not associated with warm years or El Niño events. There was, however, an association between water temperatures and mortality rates. Die-offs proceeded more rapidly in warm than cold instances $(r=0.77$, $\mathrm{df}=7, \mathrm{p}<0.01)$. Overall, there was no relationship between changes in abalone density and changes in kelp density (Fig. $3 ; r=0.051$, $\mathrm{df}=21, \mathrm{p}>0.05$ ) and no significant association between changes in abalone and sea urchin densities to indicate competition for resources was responsible for changes in abalone density (Fig $4 ; \mathrm{r}=-0.236$, $\mathrm{df}=21, \mathrm{p}>0.05$ ). Abalone density changes were not associated with changes in kelp or urchin abundance even when we incorporated time lags (i.e. the correlation coefficient was not significant for 1 to 4 yr temporal delays between urchin or kelp density and changes in abalone density). A non-significant association was found for all sites analyzed individually except Crook Pt. (CP), where there was a significant positive association between changes in kelp and abalone abundance $(\mathrm{r}=0.897, \mathrm{df}=3, \mathrm{p}=0.04)$. The other 3 sites (W, JL, NT) had non-significant negative associations between kelp and abalone.

Withering syndrome has spread over the past several years (Fig. 5). As previously mentioned, WS was first observed and presumably started on the south side of Santa Cruz Island around 1985 (unpubl. obs. of commercial abalone fishermen). By 1986, WS spread east to Anacapa Island and west to the south side of Santa Rosa Island. In 1987, WS reached the northwest sides of Santa Cruz Island. Santa Rosa Island and Santa Barbara Island to the southeast were impacted in 1988. By 1990, many areas on San Miguel Island had diseased abalone and a massive die-off was underway at San Clemente Island, the southernmost of the California Channel Islands. Recently (1992), we have seen diseased abalone on San Nicolas Island (pers. obs., VanBlaricom, Ruediger, Friedman, Woodard \& Hedrick unpubl.). The only apparently unaffected island is Santa Catalina (where black abalone were

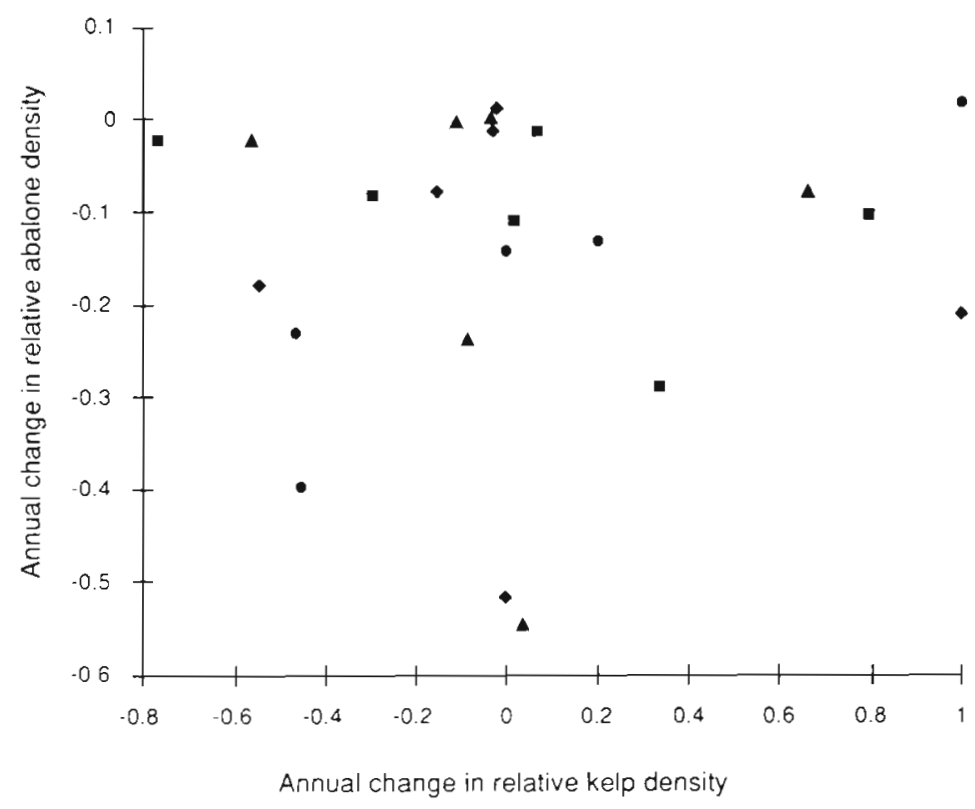

Fig. 3. Haliotis cracherodii and Macrocystis pyrifera. Changes in abalone density and changes in adult kelp density at 4 sites. $(\bullet),(\bullet) \mathrm{JL}$,

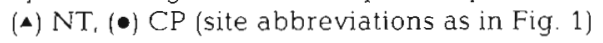

